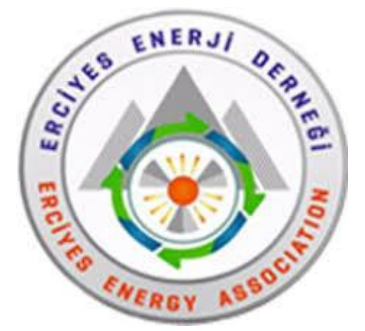

Energy, Environment and Storage

JournalHomepage: www.enenstrg.com

\title{
Evaluation of Environmental Noise Pollution (Traffic, Schools, Hospitals) and Noise Perception
}

\author{
Betül Kasagici, Nuray Ates* \\ Erciyes University, Faculty of Engineering, Department of Environmental Engineering, KAYSERI, TURKEY \\ *nuraya@erciyes.edu.tr; ORCID: 0000-0002-8923-4852
}

\begin{abstract}
Nowadays, noise pollution, one of the crucial environmental problems as a result of increase in the population, has caused physical and psychological negativities in people's lives. The increase in the number of vehicles along with the population, the lack of infrastructure in the existing roads, misbehavior of the drivers due to the lack of education lead to an increase in noise pollution. The current study aimed to determine how much noise pollution that people are exposed to in traffic, schools and hospitals in Kayseri, one of the most important industrialized centers in Turkey with a population approximately 1.4 million. The levels of noise pollution averagely varied between $62-72 \mathrm{dBA}$ in the streets and it is observed that the noise level changes depending on the vehicle intense in traffic. The noise levels in schools ranged from 41 to $57 \mathrm{dBA}$ in the morning when window was closed that were higher than the regulation limit. The noise levels in hospitals were between 46 and $58 \mathrm{dBA}$ when window is closed. The results of the survey conducted among a total of 153 people showed that noise was considered as environmental pollution by $98 \%$ in residential, $90 \%$ in schools and $73 \%$ in hospitals. The most noise-related health effects specified by the participants was the headache with $41 \%$ followed by frustrated and stressed with $24 \%$.
\end{abstract}

Keywords: Noise pollution, traffic noise, noise perception, health effects.

ArticleHistory: Received:12/07/2021; Revised: 28/07/2021; Accepted:09/08/2021; Available online: 23/08/2021

Doi: https://doi.org/1052924/YWKD5166

\section{INTRODUCTION}

Noise pollution is among the most important and almost certainly the most neglected environmental risks affecting health and comfort of people particularly in urban areas $[1,2]$. It was recognized as an important pollution factor for the first time at the United Nations Conference on the Human Environment held in Stockholm in 1972 [3,4]. World Health Organization pointed out "Noise must be recognized as a major threat to human wellbeing" [5]. By definition, noise is identified any unpleasant sounds that are disturbing or threatening health [6]. The major sources of noise are generally classified as traffic, railway, aircraft, wind turbine, leisure [5] and occupational [7]. Depending on duration and volume, the effects of noise on human health and comfort fall into four categories; physical effects (hearing disorders), physiological effects (increased blood pressure, irregularity of heart rhythms and ulcers), psychological effects (disorders, insomnia and late sleep, nervousness and stress) and inefficiency at work [8-10]. Besides adverse effects on human health, road-traffic noise induces depreciation of property and loss of rent, disturbance of wildlife [11]. Monetary equivalent of relatively severe noise pollution was estimated by Weinhold [12] at about $€ 146$ per month per household in 2003 prices and he/she stated it would be approximately $€ 172$ in 2011 prices.

Adverse effects of noise pollution on human health have been increasingly evident over the last couple decades $[6,13,14]$. According to the assessment threshold set out in the European Union Environmental Noise Directive, at least 100 million people in the European Union are affected by traffic noise and at least 1.6 million healthy years of life in Western Europe are lost as a result of traffic noise on the road. Therefore, the issue of noise among policymakers and the public remains an increasing concern [5]. Guideline Development Group strongly recommends reducing noise levels produced by road traffic below $53 \mathrm{dBA}$, produced by railway traffic below $54 \mathrm{dBA}$, produced by aircraft below $45 \mathrm{dBA}$, produced by wind turbines below $45 \mathrm{dBA}$ and from all leisure noise sources combined to $70 \mathrm{dBA}$ for average noise exposure [5].

Conversely, the increase in the number of vehicles, along with the population, the lack of infrastructure in the existing roads, and misbehavior of the drivers due to the lack of education has led to an increase in noise pollution. 
Especially after 1985 in Turkey the population and the number of vehicles has increased rapidly as a result of urbanization and industrialization [15]. Consequently, noise has become a serious environmental problem $[16,17]$. The environmental noise was regulated by "Regulation on the Evaluation and Management of Environmental Noise" on June 4, 2010 in the Official Gazette (no. 27601) in Turkey. Regarding to the Turkish regulation, there is a need to prepare strategic noise maps in areas where the population is more than one hundred thousand and the population density is more than 1000 per square kilometer [18]. According to the regulation on noise subjected by Ministry of Environment and Forest, the traffic noise level should be below $65 \mathrm{dBA}$ (daytime) and $60 \mathrm{dBA}$ (nighttime) in noise sensitive areas like education, health etc. Besides, the noise level was limited to $35 \mathrm{dBA}$ and $45 \mathrm{dBA}$ when windows were closed and open in interior of education facility and health facility areas, respectively.

Since it seriously affects human health, many studies have been carried out especially in metropolitan cities regarding the determination of environmental noise level and evaluation of its effects. Most of these studies are limited to either traffic, or hospital or school and some limited studies to evaluate environmental noise pollution in cities are available. Although $75 \%$ of the population in Europe live in urban areas [19], there are few studies available that have comprehensively evaluated the effects of noise pollution on people so far. The objective of this study was to determine the noise pollution caused by urban traffic, to evaluate traffic impacted noise pollution in sensitive areas like schools or hospitals and to reveal people perception towards to noise pollution. In the scope of the study, in order to determine the noise levels and its impacts on sensitive areas, 10 main boulevards, 9 schools and 7 hospitals were selected. The selected boulevards are the main arteries of the city of Kayseri, hospitals and schools are located on these boulevards. The survey was conducted with 153 people in the residential, school and hospital areas and 25 questions were asked to evaluate their perception on noise pollution. The people surveyed consisted of random people encountered on the boulevards, at the school and at the hospital during the measurement.

\section{MATERIALS AND METHODS}

\subsection{Description of Study Area}

Kayseri, one of the central areas of culture, art, science and tourism in Turkey, has maintained its importance in every period since history's ancient cradle of civilization. According to 2017 TURKSTAT data, the population of the province is about 1.4 million [15] and is located in southern part of Central Anatolia in Turkey. It has an area of $16.913,8203 \mathrm{~km}^{2}$ and a traffic network length of about $2288 \mathrm{~km}$. The city is expanding, and new streets are being built and added to the existing network. Noise pollution was studied in the city in 2017, during which sound levels were measured on 10 selected streets within residentialcommercial zones, as these were thought to be the most representative of streets across the city.

\subsection{Noise Measurements}

The investigation and evaluation of environmental noise pollution was conducted in noise sensitive areas such as hospitals, schools and streets in the most densely populated areas of Kayseri (Turkey) during the period of spring season between April to June 2016. For the purpose of the study, 10 streets, 9 schools and 7 hospitals were selected in the most densely populated areas in the city. The list of measurement points and their locations are given in Table 1 and Fig 1 . The noise levels were monitored between the hours of 08:00 and 09:30 in the morning and between the hours of 17:00 and 19:00 in the evening. The measurement time interval, commuting to work hours were chosen as the time when the traffic was the busiest and the noise level was the highest. During this study, street noise measurements were carried out in the city center of Kayseri on the streets and boulevards where the noise of motor vehicles was dense. On the streets and boulevards, the noise was measured at 3 points (the beginning, middle and end of the street) of each street for 3 weeks on Monday, Wednesday, Friday and Sunday. In hospitals and schools, relevant noise measurements were taken in the sections facing the street and settlement areas while the windows were open and closed. The outdoor measurements were carried out at an elevation of 1.5 meters from the floor and kept at least $2 \mathrm{~m}$ away from the walls and surrounding obstacles. The measurements at each point were repeated three times.

Table 1. The list of measurement points

\begin{tabular}{|c|c|c|}
\hline Streets & Schools* & Hospitals* \\
\hline Osman Kavuncu (St1) & Nursery School (Sc1) & H1 \\
\hline Kocasinan (St2) & Secondary School (Sc2) & H2 \\
\hline Sivas (St3) & Primary School (Sc3) & H3 \\
\hline Istasyon (St4) & High School (Sc4) & H4 \\
\hline Ahmet Pasa (St5) & Primary School (Sc5) & H5 \\
\hline Nato (St6) & Primary School (Sc6) & H6 \\
\hline Tuna (St7) & $\begin{array}{c}\text { Technical High School } \\
\text { (Sc7) }\end{array}$ & H7 \\
\hline Talas (St8) & High School (Sc8) & \\
\hline Meliksah (St9) & High School (Sc9) & \\
\hline Bilge Kagan (St10) & & \\
\hline *Due to the confidentiality of the data, the names of the schools and \\
bospits hidde
\end{tabular}
hospitals are hidden.

The noise measurements with the A-weighting scale (dBA) was determined using the Testo 816-1 Sound Level Meter. The Testo 816-1 allows measuring in the range of 30 to $130 \mathrm{dBA}$ with two-time weightings, two frequency weightings, has minimum and maximum value functions, and allows individual value storage as well as measurement series storage. The device was calibrated in accordance with the operating manual before measuring the sound levels in selected points. A continuous sound measurement was recorded for 5-minute intervals and the sound levels considered were LAeq, Lmax and Lmin. 
Noise levels monitored in the streets at three points were analyzed by kriging method, which is a spatial interpolation method, and noise distribution maps for Kayseri have been created. Spatial interpolation methods are frequently used to create spatial distribution maps from point data. Spatial interpolation is an estimate of the values of non-measured points by using the values of the sampled points.

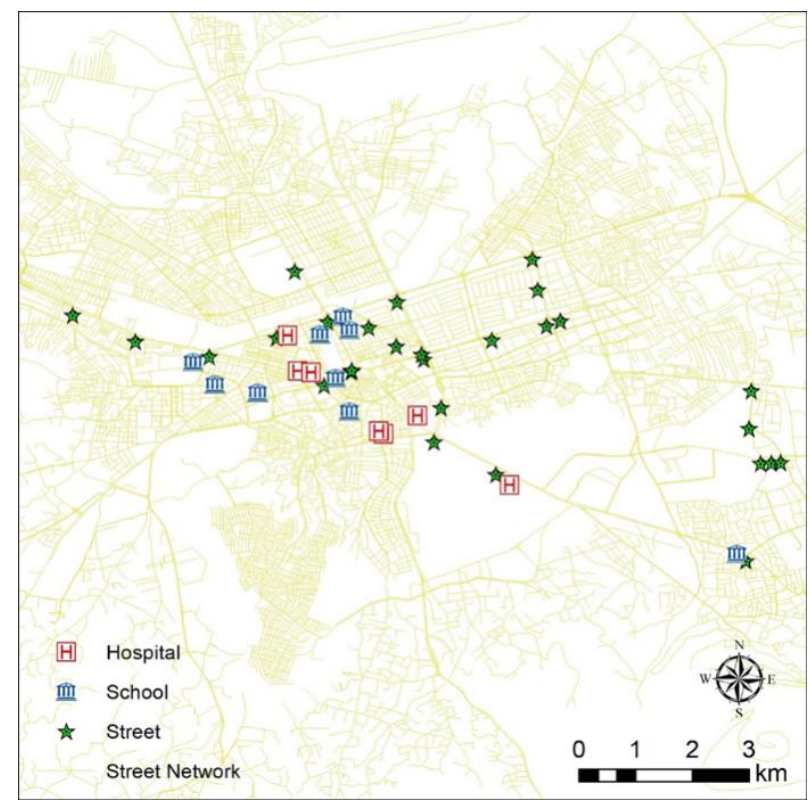

Figure 1. The location of measurement points.

\subsection{Survey Study}

A survey was conducted at the hospitals, schools, and streets to evaluate the perception about noise. Survey questions were prepared to evaluate the perceptions that people have about noise pollution and socio-economic characteristics of individuals such as gender, age, occupation and education. A questionnaire consisting of 25 questions was conducted among randomly selected 153 people and face-to-face interviews were performed. The questions in the survey had multiple choice and the respondents could select more than one answer.

\section{RESULTS AND DISCUSSION}

\subsection{Traffic Noise}

Of all environmental related health problems, traffic-noise has been reported to be the most health-threatening stressors in Europe, with almost invariable affecting the entire urban populations at varying degrees [20]. In the current study, the average noise levels for ten streets in Kayseri are given in Figure 2 and the spatial distribution of noise levels are shown in Figure 3. On the weekdays, the noise levels on the streets varied between $62 \mathrm{dBA}$ and $72 \mathrm{dBA}$ in the morning hours and $62 \mathrm{dBA}$ and $70 \mathrm{dBA}$ in the evening hours. While the noise levels were higher during morning hours on Monday (Figure 2A), almost similar noise levels were measured on Wednesday (Figure 2B) and Friday (Figure 2C) during morning and evening hours. Overall, the noise levels during evening hours were higher than morning hours on Sunday (non-working day in Turkey). This is attributed to fact that people have the habit of resting at their homes and departing at different times at morning hours on Sunday. On the other hand, people end their social activities at similar times in the evening hours. The lowest noises were detected at Bilge Kagan Streets (St10) on weekdays and weekend. On weekdays, the noise levels were almost similar with around $70 \mathrm{dBA}$ at all streets, except Meliksah (St9) and Bilge Kagan (St10) Streets. The streets on which the highest levels of traffic noise were recorded are characterized by heavy traffic as they are located in the densely populated and commercialized part of the city.

The statistical significance (ANOVA) of noise level at streets was evaluated based on weekdays and streets. The results of the ANOVA exhibited that there is no significant difference $(p>0.05)$ between the average noise levels on the streets on morning and evening periods or in days when all street points are considered individually or together. In Turkey, traffic noise level should be below 65 $\mathrm{dBA}$ and $60 \mathrm{dBA}$ during daytime and night time respectively in noise sensitive areas like education, health, etc. [17]. In all streets (except St10), the noise levels measured in the morning and evening are higher than the upper limit values specified by regulations either by local or international institutes, even on Sundays.

In a study of noise pollution evaluation in Abuja (Nigeria), day time mean noise level varied from 73.2 dBA to 83.6 dBA in 35 different points in the city [21]. That is much higher than the noise levels which were observed than this study. On the other hand, the noise levels at different streets in the city of Yazd (with a population of 430,000 in 2007) were reported between typically $70.9 \mathrm{dBA}$ and 80.7 dBA [22]. Korfali and Massoud [23] observed noise levels greater than $70 \mathrm{~dB}$ in Lebanese urban areas and the highest noise level was reported as $79 \mathrm{~dB}$. They attributed high measured noise levels to the high percentages of perceived traffic noise (88.5 and 90\%) and motorcycles $(82 \%)$. Birma et al. [24] evaluated noise pollution in Warri and Effurun Metropolitan Cities at 22 monitoring stations during the morning, afternoon, and evening periods and they did not observe significance difference within the different periods of the day at each sampling station. However, there is significant variation $(\mathrm{p}<0.05)$ in the mean noise values at each period of the day over all the sampling stations. The results of Seong et al. [25] on modeling road traffic noise in Fulton County revealed that the noise level of $55 \mathrm{~dB}(\mathrm{~A})$ or higher affected $48 \%$ of the total county population during daytime. On the other hand, $32 \%$ of the population is exposed to noise levels greater than $50 \mathrm{~dB}(\mathrm{~A})$ at night time.

Although traffic noise affects everyone living in the city, the most severe impact is seen in people who are closely involved in traffic such as drivers, passengers and pedestrians. Cai et al. [26] reported that higher levels of Creactive protein, triglycerides, HDL cholesterol, and fasting glucose were significantly related with higher long-term traffic noise in densely populated areas. Sørensen et al. [27] stated that the risk of heart attack increased by 12 percent for every 10 decibels added to road traffic noise. 

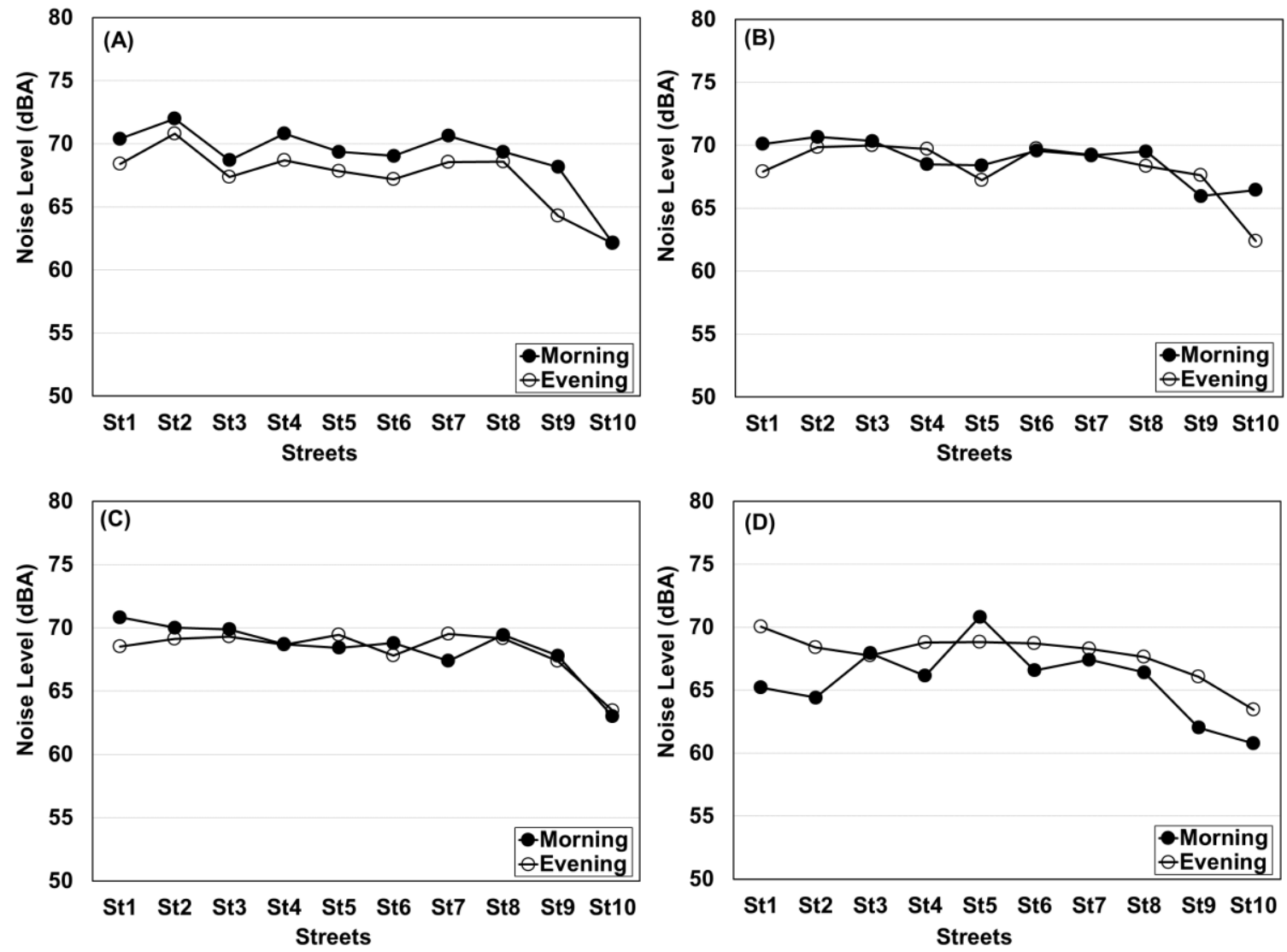

Figure 2. Average noise levels on the streets on Monday (A), Wednesday (B), Friday (C) and Sunday (D) in the morning hours of 08:00-09:30 and in the evening hours of 17:00-19:00.

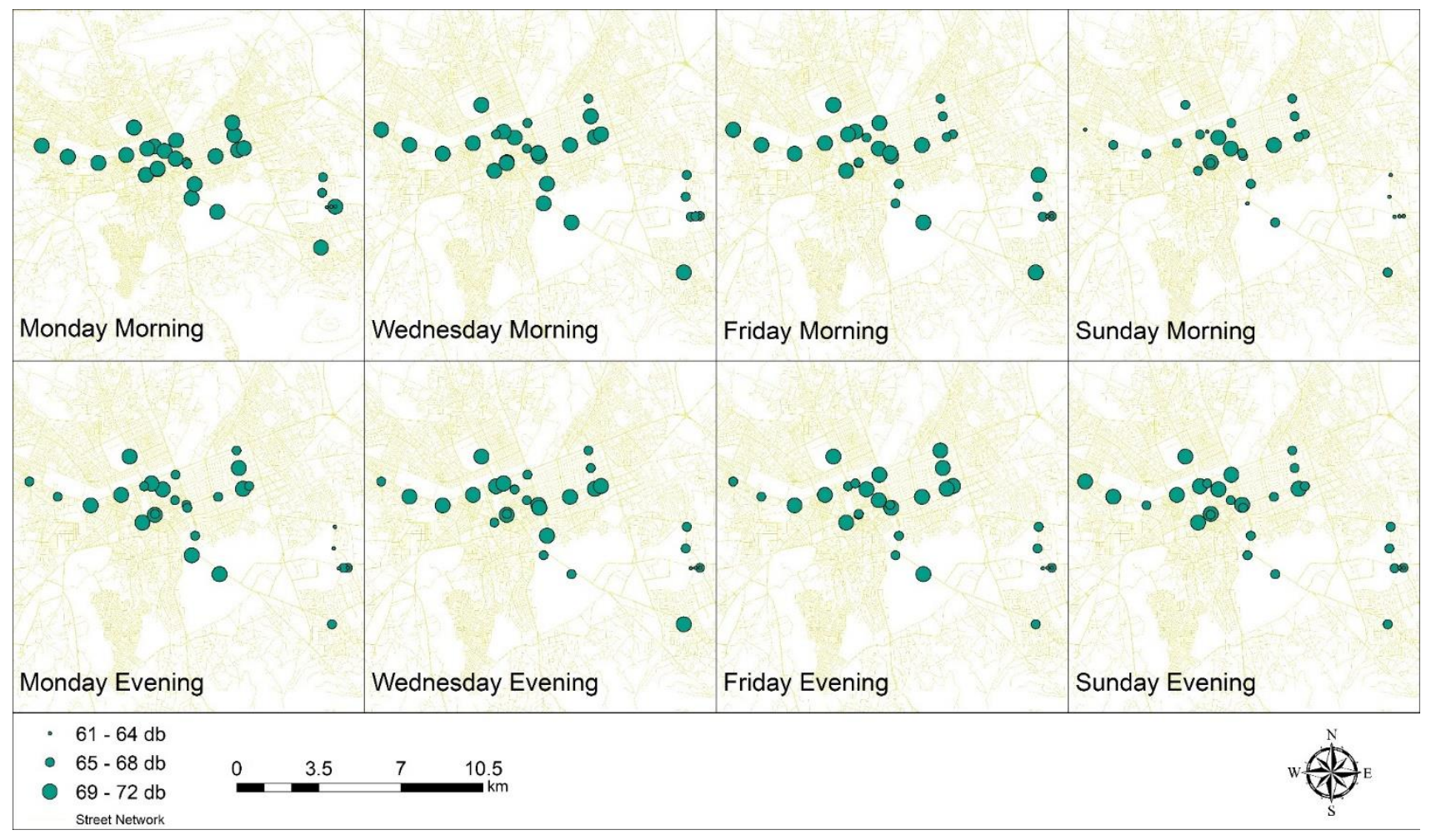

Figure 3. Spatial distribution of noise levels in the streets.

The studies reported prevalence of noise-induced hearing loss of $42.2 \%$ in the city of Curitiba, $55.5 \%$ (1998) and $46 \%$ (2000) in the city of São Paulo [28], 13\% in Finland [29] and $21 \%$ in Mexico [30]. Hearing loss in drivers is important because of prolonged exposure to loud noise throughout the day, such that left ear shows more loss than right ear [31-33]. de Kluizenaar et al. [34] revealed that long-term exposures of noise lead to increased morning 
tiredness on truck drivers. On the other hand, 10 years old children at home exposed to road traffic noise is much more inclined to behavioral problems and increased hyperactivity [35]. Noise pollution may lead to several personal disabilities, handicaps, and behavioral changes including fatigue, uncertainty, lack of self-confidence and concentration, irritation, misunderstandings, decreased working capacity, disturbed interpersonal relationships, and stress reactions. The effects of traffic noise on human behaviors can lead to increased accidents, impaired communication in the classroom and impaired academic performance [36].

\subsection{Noise Pollution in the Schools}

In the scope of the study, the indoor and outdoor noise levels were determined in 1 kindergarten, 4 primary and 4 high schools for a total of 9 schools. To assess the effect of outdoor noise, measurements were performed with closed and open windows in the closest classroom to the outdoor noise source. The observed average values are presented in Figure 4. The noise levels varied between 41 and $57 \mathrm{dBA}$ in the morning when window was closed. The highest noise level was detected at Sc6 school, and the lowest noise was recorded at $\mathrm{Sc} 3$ school. On the other hand, the lowest noise was observed at Sc9 school with 39 $\mathrm{dBA}$ in the evening. Similar to the morning measurement, Sc3 school was the school where the highest noise level was observed in the evening. On the contrary, the other schools, the morning and evening noise levels did not change significantly, such as Sc5, Sc6, Sc7 and Sc8 schools. While the window was in the open position, the minimum and maximum noise levels were observed at Sc2 school with $52 \mathrm{dBA}$ and Sc6 with $68 \mathrm{dBA}$ in the morning (Figure 4B).

The outdoor noise measurements were almost similar with the values of window open position in the morning and varied between 52 and $68 \mathrm{dBA}$. However, the noise levels at outdoor locations were much higher than in the classroom when window open in the evening (Figure 4C). The highest noise was observed with $68 \mathrm{dBA}$ at Sc6 school with either the window open or outdoors in the morning. The Sc4 school was among the schools was exposed to the highest outdoor noise with $71 \mathrm{dBA}$ in the evening. According to the regulation on noise by Ministry of Environment and Forest, the noise levels inside classrooms were limited at $35 \mathrm{dBA}$ and $45 \mathrm{dBA}$ when with the windows closed and open, respectively. The noise measurements in all schools clearly showed that the noise levels were much higher than regulation limits with the windows in either the open or closed position.

Similarly, traffic-related noise problem (56-77 dBA) was reported in one school, which was located near highway in a study conducted in Malesia in three different schools. Teachers and students participated to the survey study pointed out disturbance of study/teaching (27\%), hearing problem during classes $(26 \%)$ and mental stress (17\%) as the most common problem among the negative effects of traffic noise [37]. Forns et al. [38] indicated a positive association between noise exposure (38-51 dBA) at school and attention deficit/hyperactivity disorder symptomatology. Studies revealed that increased blood pressure [39] and annoyance reactions [40] were observed on children exposed to traffic related noise.
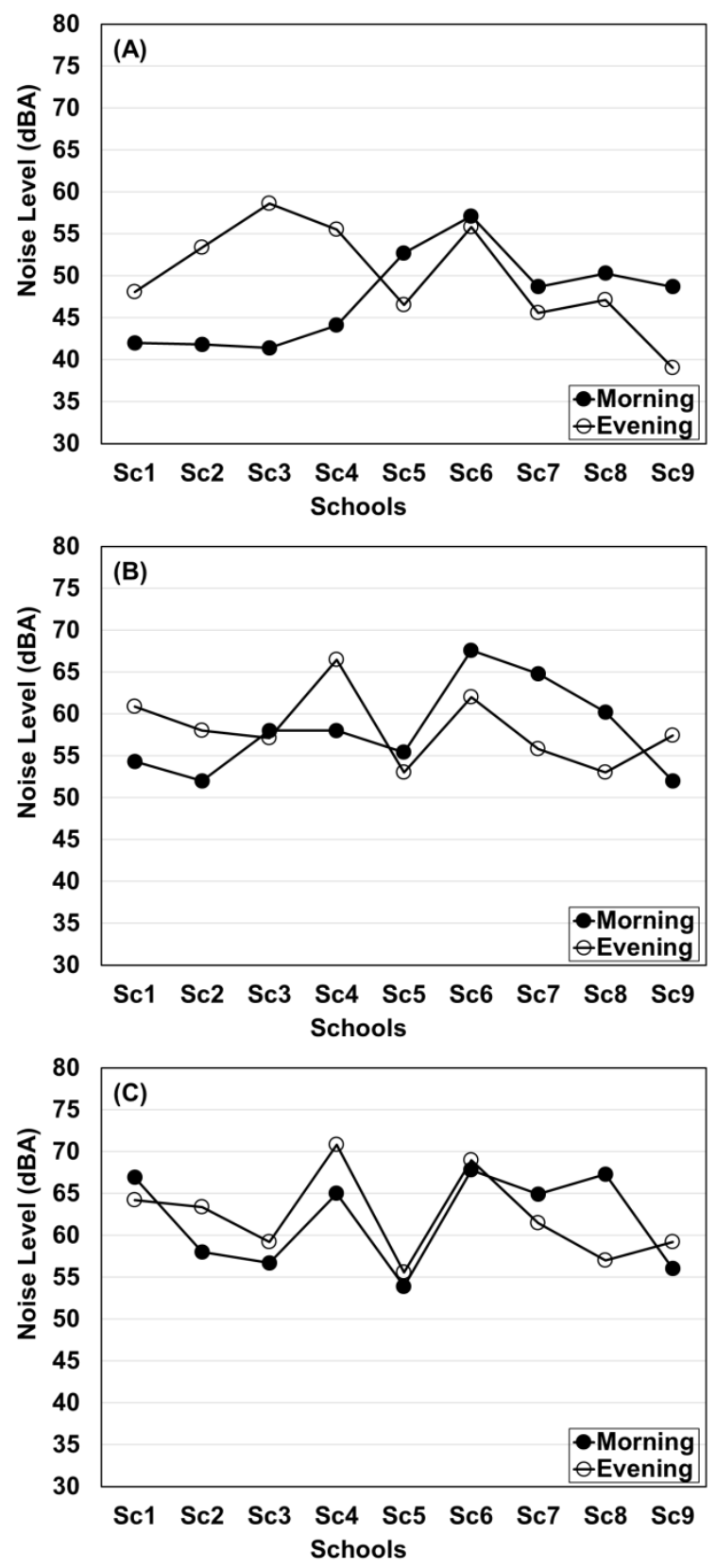

Figure 4. Average noise levels at schools: window closedindoor $(\mathrm{A})$, window open-indoor $(\mathrm{B})$, outdoor $(\mathrm{C})$ in the morning hours of 08:00-09:30 and in the evening hours of 17:00-19:00.

\subsection{Noise Pollution in the Hospitals}

Noise level was monitored in 7 private and governmental hospitals for three weeks and the noise level was measure three times at morning and evening between 08:00-09:30 and 17:00-19:00, respectively in different times with the window open and closed. In order to evaluate the longterm effects of noise on physiological and physiological health of patients and healing duration, noise measurements were performed in patient rooms. The observed results are presented in Figure 5. The noise levels varied between 46 and $58 \mathrm{dBA}$ when window is closed (Figure 5A). The highest and the lowest noise levels were at $\mathrm{H} 2$ and H6hospitals. In fact, the noise levels 
in all hospitals except $\mathrm{H} 2$ and $\mathrm{H} 3$ hospitals were varied in the narrow range of 55 and $58 \mathrm{dBA}$ in the morning time. On the other hand, the noise levels in hospitals in the evening time when the window was closed were between 45 and $56 \mathrm{dBA}$, similar to the morning time. Although the noise levels at morning and evening times in the $\mathrm{H} 1, \mathrm{H} 2$ and $\mathrm{H} 3$ hospitals were almost the same, the noise levels at the evening time declined by 6 to $13 \mathrm{dBA}$ similar to the morning values in other hospitals. Lower noise levels in hospitals at evening time was attributed to the quantity of patients. In particular, H1 hospital having the most capacity with 4 million patients annually, is always very crowded at day or night. Durduran et al. [41] reported higher noise levels in the morning than in the afternoon and evening.

Almost similar noise levels were observed when the window is opened in all hospitals and there is no significance difference $(p>0.05)$ in noise levels between morning or evening measurements (Figure $5 \mathrm{~B}$ ). The noise levels ranged between 54 and $62 \mathrm{dBA}$ in the morning and 56 and $62 \mathrm{dBA}$ in the evening when window was open. Similar to noise measurements in the morning, the highest noise level was detected at $\mathrm{H} 1$ hospital. The noise levels were almost increased by 4 to $10 \mathrm{dBA}$ when the window was opened. Higher noise levels were observed during evening measurements at $\mathrm{H} 1$ and $\mathrm{H} 7$ hospitals gardens, measured at $70 \mathrm{dBA}$ and $58 \mathrm{dBA}$ respectively. This might be attributed to the location of the hospital in the city, its distance to the street, the size of the hospital or immediate circumstances. All hospitals except $\mathrm{H} 7$ hospital are located in the center of Kayseri. $\mathrm{H} 1$ and $\mathrm{H} 7$ hospitals are on the main boulevards however the other hospitals are placed are more distant than the main roads. The noise measurements presented an exceptional example of $\mathrm{H} 4$ hospital that is near to one of the main roads in Kayseri, although the lowest noise was detected when window is open or in the garden (Figure 4C). The reasonable explanation for this example is that the hospital is placed in a planted garden and the hospital garden provides buffer zone for the noise pollution from the street. The values obtained in this context show that it is important to construct sensitive areas in quieter areas of the city. According to the regulation on noise by the Ministry of Environment and Forest, noise levels are limited at 35 $\mathrm{dBA}$ and $45 \mathrm{dBA}$ when windows are closed and open in interior of health facility areas, respectively. According to measurements, the noise levels in all hospitals were exceeded the regulation limits for both the window closed and open situations. Grumet [42] reported that length of stay in hospital increased with higher noise levels and stated that noise control in hospitals should be considered as a priority issue. Allaouchiche et al. [43] monitored noise levels in postanaesthesia care units and reported that the mean, maximum and minimum noise levels as 67,76 and $49 \mathrm{dBA}$, respectively.

In the study of Tsiou at. al. [44], noise level was evaluated in terms of Leq and its sources were identified during 43 surgeries in operating rooms. The result of the study revealed that the level of noise during the main procedure of an operation was Leq=71.9 $\mathrm{dB}(\mathrm{A})$ and machinery, tools, and conversation of people in the operating room were the noise sources. The noise levels at policlinics, clinics and other places (radiology, laboratories, and from corridors) during day-time in University Hospital in Samsun were $57 \mathrm{~dB}(\mathrm{~A}), 53 \mathrm{~dB}(\mathrm{~A})$ and $61 \mathrm{~dB}(\mathrm{~A})$, respectively [45].

Since hospitals are sensitive areas regarding noise pollution, health and comfort of both patients and staff are adversely affected by high level of noise. The studies revealed that the high noise increases the stress level of the hospital staff [46] and it can even cause mental collapse [47]. Pugh and Griffiths [48] reported that noise levels higher than $50 \mathrm{~dB}$ (A) caused sleep disorder in hospital patients. The research among nurses showed that long-term exposure to noise caused emotional exhaustion, depersonalization, and decreased personal accomplishment [47].
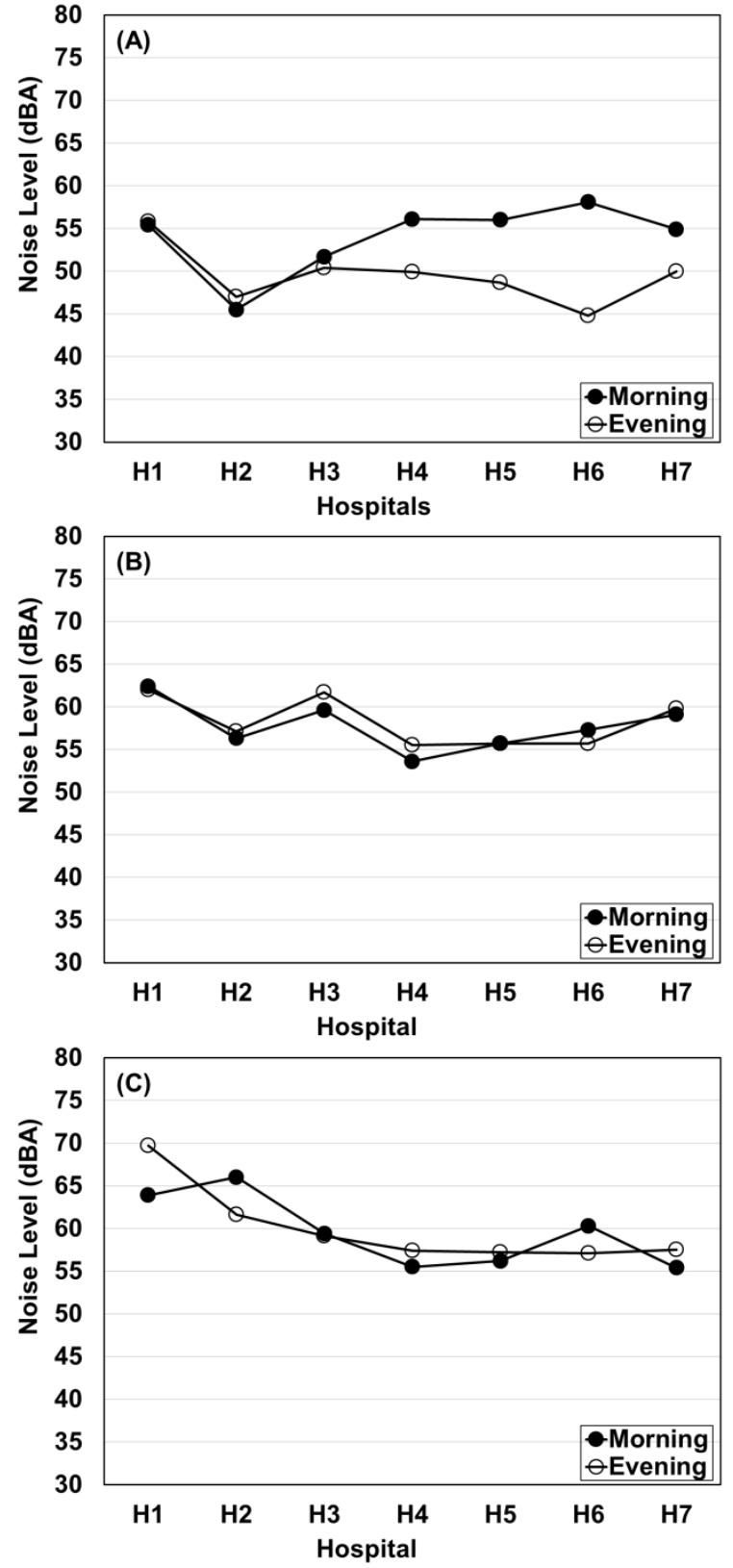

Figure 5. Average noise levels at hospitals: window closed-indoor (A), window open-indoor (B), outdoor (C) 
in the morning hours of 08:00-09:30 and in the evening hours of 17:00-19:00.

\subsection{Perception Survey for the Evaluation of Noise Pollution}

The survey was performed among 153 people and the socioeconomic characteristics of the sampled population are presented in Table 2 . Of the 153 people surveyed, 80 were female and 73 were male. The distribution of female is $25 \%, 39 \%$ and $36 \%$, the distribution of males is $43 \%$, $27 \%$ and $30 \%$ in residential areas, school and hospitals, respectively. 22 of the respondents stated that they had received elementary school, 16 secondary schools, 51 high schools, 13 high schools, 43 graduate and 9 graduate students. Although no educational privileges were considered during the survey, it was observed that those with low levels of education were worried about participating in the survey. The participants stated 23 are workers, 44 are civil servants, 38 are students, 21 are housewives and 23 are self-employed among the 153 participants.

According to the evaluation of survey data in residential, schools and hospitals, it was concluded that noise was considered as environmental pollution by $98 \%$ of the participants in residential, $90 \%$ in schools and $73 \%$ in hospitals. Noise sources were evaluated and the participants, $73 \%$ in residential, $68 \%$ in schools and $70 \%$ in hospital stated that the source of the noise was mostly found outside the house.

Table 2. Socioeconomics characteristics of individuals in the survey

\begin{tabular}{|l|l|c|c|c|}
\hline Parameter & & Residential & School & Hospital \\
\hline \multirow{5}{*}{ Gender } & Female & 20 & 31 & 29 \\
\cline { 2 - 5 } & Male & 31 & 20 & 22 \\
\hline \multirow{5}{*}{ Education } & $\begin{array}{l}\text { Primary } \\
\text { School }\end{array}$ & 14 & 3 & 5 \\
\cline { 2 - 5 } & $\begin{array}{l}\text { Secondary } \\
\text { School }\end{array}$ & 11 & 2 & 3 \\
\cline { 2 - 5 } & High School & 14 & 10 & 27 \\
\cline { 2 - 5 } & Collage & 5 & 2 & 6 \\
\cline { 2 - 5 } & Undergraduate & 5 & 29 & 9 \\
\cline { 2 - 5 } & Graduate & 3 & 5 & 1 \\
\hline \multirow{5}{*}{ Occupation } & Worker & 7 & 5 & 11 \\
\cline { 2 - 5 } & Officer & 2 & 29 & 13 \\
\cline { 2 - 5 } & Student & 10 & 13 & 15 \\
\cline { 2 - 5 } & Housewife & 12 & 4 & 5 \\
\cline { 2 - 5 } & $\begin{array}{l}\text { Self- } \\
\text { employment }\end{array}$ & 21 & - & 2 \\
\hline
\end{tabular}

The noise sources were classified as industry, transportation, unplanned urbanization, rapid population growth and human activities (street entertainment, construction works etc.) by the participants. $28 \%$ of the total number of participants indicated that the noise was caused by transportation vehicles and $21 \%$ was due to unplanned urbanization. It was reported that highways cause the most noise from the transportation group, which includes highway $(69 \%)$, railway $(21 \%)$ and airport $(10 \%)$ categories. Automobiles (74\%) and motorcycles (51\%) have the most principal impacts on noise for transportation based on the received highest number of responses. When the participants were asked which place was most disturbed by the noise, the majority reported $36 \%$ home and the second most with $29 \%$ was traffic. The most disturbing time for noise for $50 \%$ of participants was during day-time between 07:00 and 19:00. For 48\% of participants it was night-time between 19:00 and 23:00, and for the rest it was midnight.

In order to evaluate the effects of noise on health, the participants were asked which of the effects of noise they felt, such as frustration and stress, ineffectiveness in work, headache, and fatigue. The most prevalent impact of noise among the people in residential was headache with $41 \%$ followed by frustration and stress with $24 \%$. On the other hand, $31 \%$ of the participants in the hospital suffered from headache, $33 \%$ of the participants in the school complained being frustrated and stressed. The ineffectiveness in work (14\% in residential, $23 \%$ in school and $12 \%$ in hospital) was the third most common in all three groups following frustration, stress and headache. $12 \%$ of the participants reported that their relatives had noise related health problems. The participants were asked what kind of health problems affecting their relatives that had been caused by noise. Symptoms such as sleep disorder, stress related circulation disorder, mental problems, hearing impairment, social behavior disorders, motivation and communication disorders were among the effects caused by noise pollution. $85 \%$ of the participants responded with yes when asked whether tiredness caused by noise can cause accidents. Of the participants, 119 agreed that various noises affect the work to be done on time and accurately. A survey among 2391 people performed by Sundstrom et al. [49] showed that decreasing job satisfaction was significantly related with high level of noise. For half of the participants, preventing or reducing noise is considered as very important in terms of quality of life. $49 \%$ of the participants think that they have enough knowledge about the precautions to be taken to prevent noise. Among the main measures that can be taken for the prevention of noise are the prohibition of making noise, prohibition of causing high noise after certain hours, increasing inspections and the introduction of noise limit values.

The most important precaution taken to reduce the noise for the participants in residential $(28 \%)$ and in school $(33 \%)$ was the isolation of buildings and the prevention of traffic-related noise for the participants $(35 \%)$ in hospital. $83 \%$ of the participants answered no for the question of "Do you think that efforts to stop noise pollution have been sufficient?" 91 out of 153 people reported to the authorities by phone call that they were disturbed by noise. However, 71 participants stated that their complaints about noise pollution were not resolved. 


\section{CONCLUSION}

The noise levels monitored in the streets varied between $62 \mathrm{dBA}$ and $72 \mathrm{dBA}$ in the morning hours and $62 \mathrm{dBA}$ and $70 \mathrm{dBA}$ in the evening hours on weekdays. The noise levels in the streets located in the city center were much higher than located in suburban streets. There is no significance difference $(p>0.05)$ in noise levels between morning and evening hours during weekdays. However, the noise levels on evening hours were, in general, higher than morning hours on Sunday. This fact is attributed to that people are generally resting at their homes and departing at different times in the morning hours of Sunday.

The noise levels in the schools were varied between 41 $\mathrm{dBA}$ and $57 \mathrm{dBA}$ in the morning and between $39 \mathrm{dBA}$ and $56 \mathrm{dBA}$ in the evening when windows were closed. The noise was as high as $68 \mathrm{dBA}$ when windows were open and $71 \mathrm{dBA}$ in the outdoors regardless of whether it was morning or evening. The results obtained in schools showed that the noise level values recorded in the classrooms facing the settlement areas were lower than the measurements conducted in the classrooms facing the street side. The schools where low noise measurements recorded, generally, have buffer structures (e.g., planted garden or wall) that prevents the environmental noise such as traffic. The higher noise levels recorded in classrooms when windows were closed were the result of old building structure, the weakness of the insulation structures or distance from main boulevard.

The monitoring of noise in the hospitals showed that the noise levels were varied between 46 and $58 \mathrm{dBA}$ in the morning and 45 and $56 \mathrm{dBA}$ in the evening, when windows were closed. On the other hand, the noise levels were ranged between 54 and $62 \mathrm{dBA}$ in the morning and 56 and $62 \mathrm{dBA}$ in the evening when windows were open. The lowest noise level observation in $\mathrm{H} 4$ might be attributed to the hospital being placed in a planted garden and the hospital garden provides a buffer zone for the noise pollution from the street.

According to the responses by participants to the survey, $98 \%$ in schools, $90 \%$ in schools and $73 \%$ in hospitals say that noise is considered as environmental pollution. Among the 153 of participants, transportation and unplanned urbanization were indicated by $28 \%$ and $21 \%$ of the participants respectively as the major noise sources in the city. The most prevalent impact of noise among the participants was headache followed by frustration, stress and ineffectiveness in work.

Most of the participants agreed that noise has significant effects on timely and accurate work. According to half of the participants, reduction in noise pollution is crucial in terms of quality of life. Reduction in noise levels could be achieved by the prohibition of making noise, the prohibition of causing high noise after certain hours, isolation of the structures, increasing inspections and enforcement of existing law, and introduction of noise limit values.
In order to prevent noise pollution and decrease the level, as well as serious precautions should be taken, it is necessary to give importance to city planning, to insulate buildings, to increase the level of education and awareness of people. Sensitive areas such as the school and hospital to be established should be located after the noise analysis in the region. In addition, it should be planned to be well insulated to outdoor noise and away from the main streets with heavy traffic. Buffer areas (trees, green refuges, green fences, etc.) should be created on the roadsides in order to prevent traffic noise from reaching residential areas, schools and hospitals.Urbanization should be planned so that business and entertainment centers, education and health areas, which cause high noise and settlement, are separated from each other.

\section{Disclosure of interest}

On behalf of all authors, the corresponding author states that there is no conflict of interest.

\section{Ethics approval and consent to participate}

No ethical approval was required as the survey was optional and anonymous, and the aims of study explained to all candidates prior to performing the survey. The questionnaires compiled in this study were conducted with random volunteer participants over 18 years of age who were met in the street, hospital or school (teachers only) during noise measurements.

\section{REFERENCES}

[1] Zannin PHT, Ferreira AMC, Szeremetta B. Evaluation of noise pollution in urban parks. Environ Monit Assess. 2006;118(1-3):423-33.

[2] Wessels PW, Basten TG. Design aspects of acoustic sensor networks for environmental noise monitoring. Appl Acoust. 2016;110: 227-34.

[3] Buss R. United Nations Conference on the Human Environment (UNCHE). June 5-16, 1972. Stockholm, Sweden: United Nations, 2007.

[4] Morillas JMB, Gozalo GR, González DM, Moraga PA, Vílchez-Gómez R. Noise pollution and urban planning. Curr Pollut Rep. 2018;4(3): 208-19.

[5] World Health Organization (WHO) (2018). Environmental Noise Guidelines for the European Region, 5. Regional Office for Europe, Copenhagen, Denmark.

[6] Singh D, Kumari N, Sharma P. A review of adverse effects of road traffic noise on human health. Fluct Noise Lett. 2018;17(01): 1830001.

[7] Choiniere DB. The effects of hospital noise. Nurs. Adm. Q. 2010;34(4): 327-33.

[8] Hsu T, Ryherd E, Waye KP, Ackerman J. Noise pollution in hospitals: impact on patients. JCOM. 2012;19(7): 301-9.

[9] Ryherd EE, Okcu S, Ackerman J, Zimring C, Persson K. Noise pollution in hospitals: impacts on staff. JCOM. 2012;19(11): 491-500. 
[10] Esmaeilzadeh-Kavaki M, Sepahi F, Dashab Z, Sheikh-Amirlou M, Hashemi M. Noise pollution in hospitals. Arch Occup Health. 2018;2(3): 164-9.

[11] Lauper E, Moser S, Fischer M, Matthies E. Explaining car drivers' intention to prevent road-traffic noise: an application of the norm activation model. Environ Behav. 2016;48(6):826-53.

[12] Weinhold D. The happiness-reducing costs of noise pollution. J Reg Sci. 2013;53(2): 292-303.

[13] Brown A, van Kamp I. WHO environmental noise guidelines for the European region: a systematic review of transport noise interventions and their impacts on health. Int J Environ Res Public Health. 2017;14(8):873-917.

[14] Wothge J, Belke C, Möhler U, Guski R, Schreckenberg D. The combined effects of aircraft and road traffic noise and aircraft and railway noise on noise annoyance-An analysis in the context of the joint research initiative NORAH. Int $\mathbf{J}$ Environ Res Public Health. 2017;14(8): 871.

[15] The office of National Statistics. (2017). Population statistics in Turkey. http://www.turkstat.gov.tr.

[16] Ozer S, Yilmaz H, Yeşil M, Yeşil P. Evaluation of noise pollution caused by vehicles in the city of Tokat, Turkey. Sci Res Essays. 2009;4(11):1205-12.

[17] Sisman EE, Unver E. Evaluation of traffic noise pollution in Corlu, Turkey. Sci Res Essays. 2011;6(14):3027-33.

[18] Regulation on the Evaluation and Management of Environmental Noise (REMEN). 2010. Regulation on the Evaluation and Management of Environmental Noise, Official Gazette, June 4, 2010, Ministry of Environment and Urbanization, Turkey.

[19] Gan WQ, McLean K, Brauer M, Chiarello SA, Davies HW. Modeling population exposure to community noise and air pollution in a large metropolitan area. Environ Res. 2012;116:11-6.

[20] World Health Organization (WHO) (2011). Burden of disease from environmental noise: Quantification of healthy life years lost in Europe, WHO Regional Office for Europe, Copenhagen, Denmark.

[21] Anomohanran O. Evaluation of environmental noise pollution in Abuja, the capital city of Nigeria. Int J Res Rev Appl Sci. 2013;14(8): 470-6.

[22] Nejadkoorki F, Yousefi E, Naseri F. Analysing street traffic noise pollution in the city of Yazd. J Environ Health Sci Eng. 2010;7(1):53-62.

[23] Korfali SI, Massoud M. Assessment of community noise problem in greater Beirut area, Lebanon. Environ Monit Assess, 2003;84(3):203-18.

[24] Birma GJ, Ukpebor EE, Issa BR. Assessment of environmental noise pollution in Warri and Effurun Metropolitan Cities. Curr World Environ. 2018;13(3):433444.

[25] Seong JC, Park TH, Ko JH, Chang SI, Kim M, Holt JB, Mehdi MR. Modeling of road traffic noise and estimated human exposure in Fulton County, Georgia, USA. Environ Int. 2011;37(8):1336-41.

[26] Cai Y, Hansell AL, Blangiardo M, Burton PR, BioSHaRE, de Hoogh K, Doiron D, Fortier I, Gulliver J, Hveem K, Mbatchou S, Morley DW, Stolk RP, Zijlema WL, Elliott P, Hodgson S. Long-term exposure to road traffic noise, ambient air pollution, and cardiovascular risk factors in the HUNT and lifelines cohorts. Eur Heart J. 2017;38(29):2290-96.

[27] Sørensen M, Andersen ZJ, Nordsborg RB, Jensen SS, Lillelund KG, Beelen R., Schmidt EB, Tjønneland A, Overvad K, Raaschou-Nielsen O. Road traffic noise and incident myocardial infarction: a prospective cohort study. PloS one. 2012;7(6):e39283.

[28] Barbosa ASM, Cardoso MRA. Hearing loss among workers exposed to road traffic noise in the city of São Paulo in Brazil. Auris Nasus Larynx. 2005;32(1):17-21.

[29] Backman AL. Health survey of professional drivers. Scand J Work Env Hea. 1983:30-5.

[30] Ahauamada HT, Ramirez FL. Las condiciones de La salud de los condutores de autotransportes urbanos de pasajeros de la ciudad de Mexico, Bol Oficina Sanit Panam. 1991;111(4):324-32.

[31] Karimi A, Nasiri S, Kazerooni FK, Oliaei M. Noise induced hearing loss risk assessment in truck drivers. Noise Health. 2010;12(46):49.

[32] Izadi N, Sadeghi M, Saraie M. Survey of NoiseInduced Hearing Loss and Health in Professional Drivers. Health Scope. 2015;4(3): e25296.

[33] Alizadeh A, Etemadinezhad S, Charati JY, Mohamadiyan M. Noise-induced hearing loss in bus and truck drivers in Mazandaran province, 2011. Int J Occup Saf Ergon. 2016;22(2):193-8.

[34] de Kluizenaar Y, Janssen SA, van Lenthe FJ, Miedema HM, Mackenbach JP. Long-term road traffic noise exposure is associated with an increase in morning tiredness. J Acoust Soc Am. 2009;126:626-33.

[35] Tiesler CM, Birk M, Thiering E, Kohlböck G, Koletzko S, Bauer CP, Berdel D, von Berg A, Babisch W, Heinrich J. Exposure to road traffic noise and children's behavioural problems and sleep disturbance: results from the GINIplus and LISAplus studies. Environ Res. 2013;123:1-8.

[36] Goines L, Hagler L. Noise pollution: a modern plague. South Med J. 2007;100(3):287-294.

[37] Ibrahim ZH, Richard HK. Noise pollution at school environment located in residential area. Malays J Civ Eng. 2000;12(2):47-62

[38] Forns J, Dadvand P, Foraster M, Alvarez-Pedrerol M, Rivas I, López-Vicente M, Suades-Gonzalez E, Garcia-Esteban R, Esnaola M, Cirach M, Grellier J. Traffic-related air pollution, noise at school, and behavioral problems in Barcelona schoolchildren: a crosssectional study. Environ Health Pers. 2015;124(4):529-35. 
[39] Paunovic K, Stansfeld S, Clark C, Belojevic G. Epidemiological studies on noise and blood pressure in children: Observations and suggestions. Environ Int. 2011;37(5):1030-41.

[40] van Kempen EE, Van Kamp I, Stellato RK, LopezBarrio I, Haines MM, Nilsson ME, Clark C, Houthuijs D, Brunekreef B, Berglund B, Stansfeld SA. Children's annoyance reactions to aircraft and road traffic noise. J Acoust Soc Am. 2009;125(2):895-904.

[41] Durduran SS, Kunt F, Dursun S. Noise pollution mapping in Konya (Turkey) City hospitals using GIS model. J Int Environ Appl Sci. 2008;3(5):415-21.

[42] Grumet WG. Pandemonium in the modern hospital. N Engl J Med. 1993;328:433-7.

[43] Allaouchiche B, Duflo F, Debon R, Bergeret A, Chassard D. Noise in the postanaesthesia care unit. Br J Anaesth. 2002;88(3):369-73.
[44] Tsiou C, Efthymiatos G, Katostaras T. Noise in the operating rooms of Greek hospitals. J Acoust Soc Am. 2008;123(2):757-65.

[45] Kılıç A, Coşkun M, Divrik-Gökçe S, Tomak L, Pekşen Y. Determination of noise levels in different units at Ondokuz Mayıs University Medical Faculty Hospital, Public Health Days Symposium, September 28-October 1, 2005; Ankara, (in Turkish).

[46] Morrison WE, Haas EC, Shaffner DH, Garrett ES, Fackler JC. Noise, stress, and annoyance in a pediatric intensive care unit. Crit Care Med. 2003;31(1):113-9.

[47] Topf M, Dillon E. Noise-induced stress as a predictor of burnout in critical care nurses. Heart Lung: J Crit Care. 1988;17(5):567-574.

[48] Pugh PJ, Griffiths R. Noise in critical care. Care Critically Ill. 2007;23(4):105-9.

[49] Sundstrom E, Town JP, Rice RW, Osborn DP, Brill M. Office noise, satisfaction, and performance. Environ Behav. 1994; 26 (2) : 195-222. 